\title{
Gallstone ileus: Computed tomography findings
}

\author{
Safra taşı ileusu: Bilgisayarlı tomografi bulguları
}

\author{
Furkan Ufuk*, Pınar Çakmak*
}

* Pamukkale Üniversitesi Tıp Fakültesi, Radyoloji Anabilim Dalı, Denizli

\begin{abstract}
Gallstone ileus ( $\mathrm{Gl}$ ) is an unusual but serious complication of biliary stone and it is caused by a fistula between the bile ducts and stomach, duodenum or colon. Gallstone that reaches the intestinal tract can be cause ileus. Early diagnosis with imaging modalities (such as computed tomography) and treatment of ileus are of great importance for survival. In addition, accurate diagnosis of underlying cause of the ileus is also important because it will guide the surgeon.

We present a 73-year old patient with gallstone ileus preoperatively diagnosed with computed tomography (CT). CT showed gastric distention, dilated duodenal and jejunal small bowel loops, a calculus in the jejunal segment of the small bowel and enteral contrast medium reflux into the fistula tract and bile ducts.
\end{abstract}

Pam Med J 2018;11(2):161-163

Key words: Gallstone ileus, computed tomography, complication, small bowel obstruction

\section{Özet}

Safra taşı ileusu, safra yolu taşlarının nadir ancak ciddi bir komplikasyonu olup safra yolları ile mide, duodenum veya kolon arasındaki fistül nedeniyle oluşur. İtestinal sisteme ulaşan safra taşı ileusa neden olabilir. Görüntüleme yöntemleriyle (Bilgisayarlı tomografi gibi) safra taşı ileusunun erken tanısı ve ileusun erken tedavisi sağkalım açısından büyük öneme sahiptir. Ayrıca, altta yatan ileus sebebinin doğru tanısı cerrahiye yol göstereceğinden önemlidir.

Biz burada, bilgisayarlı tomografi (BT) ile operasyon öncesi safra taşı ileusu tanısı konulan 73-yaşında bir hasta sunuyoruz. BT'de midede distansiyon, duodenal ve jejunal ince barsak anslarında dilatasyon, jejunumda taş ve oral kontrast maddenin fistül traktına ve safra yollarına reflüsü gösterilmektedir.

Pam Tip Derg 2018;11(2):161-163

Anahtar sözcükler: Safra taşı ileusu, bilgisayarlı tomografi, komplikasyon, ince barsak obstrüksiyonu

\section{Introduction}

Gallstone ileus (GI) is an unusual but serious complication of biliary stone. Only $1-3 \%$ of all intestinal obstructions occur due to gallstones. GI occurs in 3/1.000 of all cholelithiasis cases and it occurs slightly more frequent in women. $\mathrm{Gl}$ is caused by fistula between the bile ducts and stomach, duodenum or colon. Gallstones that pass through the intestinal tract are usually excreted in the stool without a problem. But gallstone that reaches the intestinal tract can be cause ileus [1]. Early diagnosis and treatment of ileus are of great importance for survival. In addition, accurate diagnosis of underlying cause of the ileus is also important because it will guide the surgeon [2]. Here, we present a 73-year old patient with GI preoperatively diagnosed with computed tomography (CT). We also emphasized the typical imaging findings of $\mathrm{Gl}$.

\section{Case Report}

A 73-year-old female patient was referred to our department with a 2-day history of severe abdominal pain, distention, nausea and bilious vomiting. Abdominal distension, guarding and tenderness were detected on physical examination. Metallic and high-curved bowel sounds were heard in auscultation. Patient had hypotension $(90 / 65 \mathrm{mmHg}$ ) and low blood

Furkan Ufuk

Yazışma Adresi:Pamukkale Üniversitesi Tıp Fakültesi, Radyoloji Anabilim Dalı, Denizli.

e-mail: furkan.ufuk@hotmail.com

Gönderilme tarihi: 23.11. 2017

Kabul tarihi: 18.01.2018 
oxygen level (89\%). The patient's temperature was within normal limits. The patient had been diagnosed with type 2 diabetes mellitus for 5 years. Laboratory results showed elevated white blood count (15.100 mcL; normal value $4.000-11.000 \mathrm{mcL}$ ), and alanine transaminase (46 IU/L; normal value<42 IU/L). Elevated blood glucose (189 mg/dL; normal value $82-115 \mathrm{mg} /$ $\mathrm{dL}$ ) and C-reactive protein level $(8.7 \mathrm{U} / \mathrm{mL}$, reference value $<0.6 \mathrm{mg} / \mathrm{dL}$ ) were detected. The other laboratory values of the patient were within normal limits.

Given the results and patient complaints abdominal $x$-ray was obtained. Abdominal $x$-ray showed dilated small bowel loops which are containing air-fluid levels, compatible with ileus. For further evaluation, enteral contrastenhanced computed tomography (CT) was performed. Abdominal CT revealed biliary duct dilatation, pneumobilia and enteral contrast medium reflux into the bile ducts (Fig. 1). In addition, CT showed gastric distention, dilated duodenal and jejunal small bowel loops, a calculus in the jejunal segment of the small bowel and distal bowel loops with normal calibration (Fig. 2, 3).

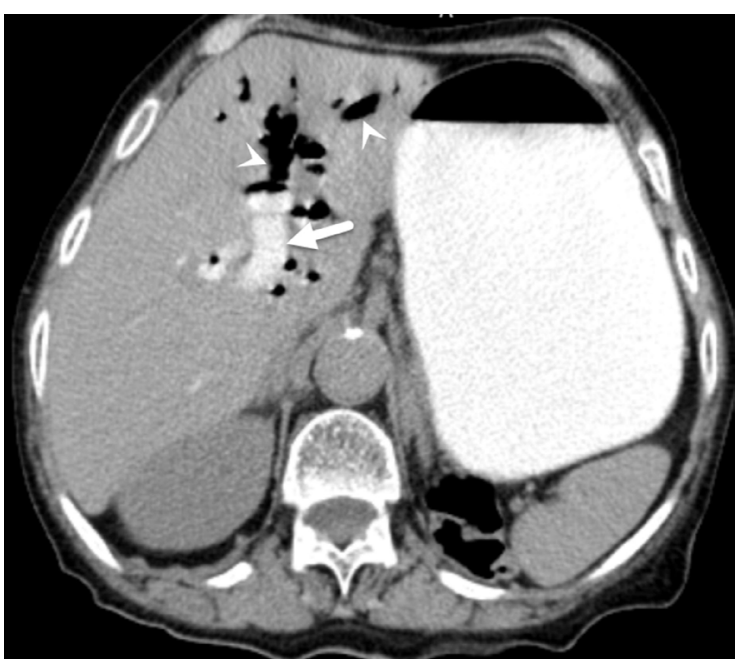

Figure 1: Axial enteral contrast-enhanced CT image of the abdomen at liver level with soft tissue window settings (window width of 300 Hounsfield units (HU) and window level of 60 $\mathrm{HU}$ ) shows enteral contrast medium reflux into the bile ducts (white arrow) and pneumobilia (arrowheads).

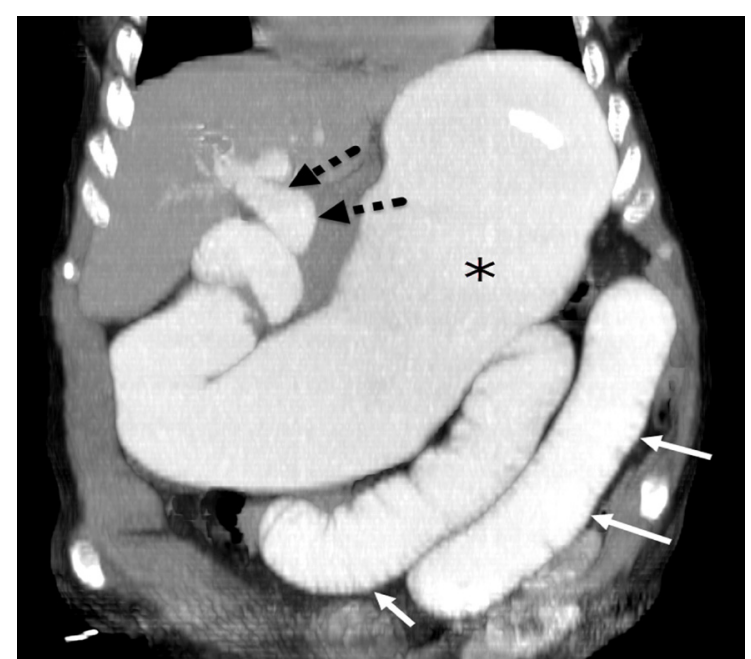

Figure 2: Coronal reformatted enteral contrastenhanced CT scan of the abdomen with soft tissue window settings (window width of 300 Hounsfield units (HU) and window level of 60 $\mathrm{HU})$ shows gastric distention $\left({ }^{*}\right)$, dilated small bowel loops (white arrows) and enteral contrast medium reflux into the fistula tract and bile ducts (black dashed arrows).

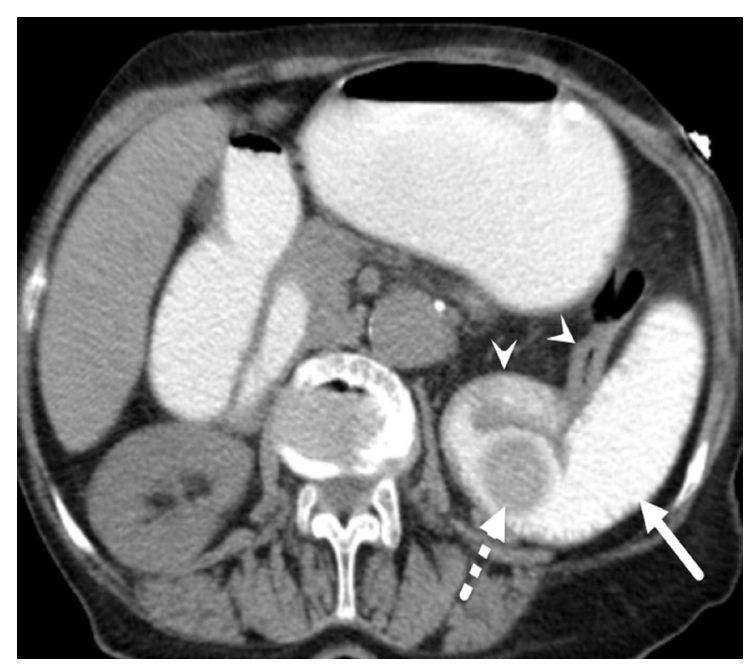

Figure 3: Axial enteral contrast-enhanced CT scan of the abdomen with soft tissue window settings (window width of 300 Hounsfield units (HU) and window level of $60 \mathrm{HU}$ ) shows dilated small bowel loops (white arrow), intraluminal gallstone (white dashed arrow) and distal bowel loops with normal calibration (arrowheads). 
The patient was operated with a preliminary diagnosis of gallstone ileus and the diagnosis was confirmed with surgery. Complaints and clinical findings of the patient were relieved after surgery and she was discharged on the 15 th day of surgery. Written informed consent was obtained from patient who participated in this case.

\section{Discussion}

Gallstone ileus is an unusual but lifethreatening complication of biliary stone. It is often seen in older ages and slightly more frequent in women, as in our case. Gallstones that reaches the intestinal tract through the fistula, such as cholecysto-duodenal or cholecysto-gastric fistula, can be cause ileus [1]. In our patient, cholecysto-duodenal fistula was present and it was displayed with CT. Approximately only in $15-20 \%$ of biliary stones are radiopaque and visible on abdominal $\mathrm{x}$-ray. Computed tomography of the abdomen has been shown to successful method in the diagnosis of $\mathrm{Gl}$ or other causes of ileus. Radiologically, Rigler triad seen in $\mathrm{Gl}$ and it consists of pneumobilia, small bowel obstruction and ectopic gallstone, as in our case. In addition, CT can also guide surgeons regarding stone size and intestinal location of obstruction [3]. In our case, preoperatively CT showed accurately size and intestinal localization of gallstone.

Gallstone ileus cannot be definitively diagnosed with history, clinical findings and physical examination. Clinical findings of the patient are usually not typical, and GI develops in later stages of cholelithiasis. Delay in the diagnosis of $\mathrm{Gl}$ has a high morbidity and mortality rates. Ayantunde et al [4] reported that an average presentation of these patients to the hospital 3 days from symptom onset. Consistent with these findings, in our case, patient was admitted with nausea, abdominal pain and bilious vomiting. The most common site of gallstone impaction has been reported as terminal ileum and ileocecal valve. Less frequent localizations have been reported as jejunum, stomach, duodenum and colon [5]. In our case, the stone was localized in the jejunum.

Bouveret syndrome is a proximal form of gallstone ileus and it refers to a gastric outlet obstruction due to impaction of a gallstone in the pylorus or proximal duodenum $[6,7]$. Rarely, Bouverte syndrome may cause acute pancreatitis [8]. Bouveret syndrome is usually seen in elderly women and patients with Bouveret syndrome are usually present with vomiting due to gastric outlet obstruction [9]. In addition to these symptoms, our patient had severe abdominal pain and dilated small bowel loops compatible with small bowel ileus.

In conclusion, gallstone ileus is a rare cause of mechanical bowel obstruction. Especially in elderly patients, GI should be kept in mind among the causes of intestinal obstruction. CT of the abdomen should be the preferred imaging method because of its rapid diagnosis and its usefulness in determining the treatment strategy.

Conflict of interest: No conflict of interest was declared by the authors.

\section{References}

1. Nuño-Guzmán CM, Marín-Contreras ME, FigueroaSánchez M, Corona JL. Gallstone ileus, clinical presentation, diagnostic and treatment approach. World J Gastrointest Surg 2016;8:65-76.

2. Yakan S, Engin O, Tekeli T et al. Gallstone ileus as an unexpected complication of cholelithiasis: diagnostic difficulties and treatment. Ulus Travma Acil Cerrahi Derg 2010;16:344-348.

3. Chuah PS, Curtis J, Misra N, Hikmat D, Chawla S. Pictorial review: the pearls and pitfalls of the radiological manifestations of gallstone ileus. Abdom Radiol 2017;42:1169-1175.

4. Ayantunde AA, Agrawal A. Gallstone ileus: diagnosis and management. World J Surg 2007;31:1292-1297.

5. Liang X, Li W, Zhao B, Zhang L, Cheng Y. Comparative analysis of MDCT and MRI in diagnosing chronic gallstone perforation and ileus. Eur $\mathrm{J}$ Radiol 2015;84:1835-1842.

6. Köksal AŞ, Eminler AT, Yıldız Savaş A, Uslan Mi, Parlak E. Endoscopic anterograde cholangiography in a patient with Bouveret's syndrome. Turk J Gastroenterol 2016;27:553-554

7. O Algın, E Özmen, MR Metin, PE Ersoy, Karaoğlanoğlu M. Bouveret syndrome: evaluation with multidetector computed tomography and contrast-enhanced magnetic resonance cholangiopancreatography. Ulus Travma Acil Cerrahi Derg 2013;19:375-379.

8. Zafar A, Ingham G, Jameel JK. "Bouveret's syndrome" presenting with acute pancreatitis a very rare and challenging variant of gallstone ileus. Int $\mathrm{J}$ Surg Case Rep 2013;4: 528-530.

9. Nabais C, Salústio R, Morujão I et-al. Gastric outlet obstruction in a patient with Bouveret's syndrome: a case report. BMC Res Notes 2013;6:195. 